\title{
Fostering of Entrepreneurship Competencies and Entrepreneurial Intentions in a Weak Ecosystem
}

\author{
Marina Solesvik \\ Professor, mzs@hvl.no \\ Western Norway University of Applied Sciences, Inndalsveien 28, 5063 Bergen, Norway \\ Paul Westhead \\ Professor, paul.westhead@durham.ac.uk \\ Durham University, Durham DH1, United Kingdom
}

\begin{abstract}
$\mathrm{T}$ his exploratory study conducted in the transitional context of Ukraine explores whether students drawn from a supportive entrepreneurship education (EE) reported higher intensity of entrepreneurial intention (IOEI) than students that did not participate in EE. Further, this study explores what specific competencies honed within a supportive EE are associated with students reporting high IOEI. Guided by competency theory, two hypotheses were tested with regard to a representative sample of 125 business EE students, and a further 64 engineering students that had never participated in EE. EE students drawn from a supportive educational entrepreneurial ecosystem were found to be associated with significantly higher IOEI. With

regard to 13 competencies honed by EE, it was found that only three competencies (the ability to identify high quality opportunities, computer literacy, and networking) were significantly albeit to a weak degree associated with higher IOEI. Additional studies are warranted in several former Soviet Union contexts to provide a rigorous evidence base to guide resource allocation decisions of the government with regard to supporting EE and entrepreneurial ecosystems. This exploratory study relating to the sample of students in one entrepreneurial ecosystem in the Ukraine does not provide conclusive evidence for the government to more proactively support the educational entrepreneurial ecosystem with regard to its current content and delivery.
\end{abstract}

Keywords: entrepreneurial ecosystem; entrepreneurship education; skills; competencies; entrepreneurial intention
Citation: Solesvik M., Westhead P. (2019) Fostering of Entrepreneurship Competencies and Entrepreneurial Intentions in a Weak Ecosystem. Foresight and STI Governance, vol. 13, no 4, pp. 60-68. DOI: $10.17323 / 2500-$ 2597.2019.4.60.68 
I ncreasing the stock of entrepreneurs is assumed to promote job generation, wealth creation, economic diversity, competition, innovation, and social well-being [Westhead et al., 2011]. Prospective entrepreneurs need to accumulate and mobilize several resources from their internal [Colombo, Grilli, 2005] and external ecosystems [Man, Lau, 2005; Westhead et al., 2011] to facilitate enterprise and to address barriers to new firm formation [Chepurenko, 2015; Kwapisz, 2019]. Several governments recognize that they may have a role to play in promoting a wider enterprise culture, particularly the formation of new knowledge and technology-based firms that can have a global sustained competitive advantage [Schwens et al., 2018; Weerawardena et al., 2019]. Governments recognize that universities have a role in promoting the fostering of supportive entrepreneurial ecosystems [OECD, 2011; Malecki, 2018; Zahra, Nambisan, 2012]. Whilst there is no agreed upon definition of an entrepreneurial ecosystem, Malecki [Malecki, 2018, p. 1] has suggested that an entrepreneurial ecosystem relates to "dynamic local, social, institutional, and cultural processes and actors that encourage and enhance new firm formation and growth". Many universities are seeking to commercialize their knowledge and they are providing entrepreneurship education (EE) to encourage more students to become entrepreneurs [European Commission, 2008]. An EE seeks to provide a positive ecosystem for enterprise and address the uncertainty associated with a career in enterprise [Gibb et al., 2009]. Notably, an EE seeks to encourage students to accumulate the competencies assumed to be required to become entrepreneurs at private, corporate, and social enterprises [NESTA, 2008]. However, governments need an evidence base to guide their direct (and indirect) resource allocations towards supporting EE and entrepreneurial ecosystems at universities.

Entrepreneurship is a process [Low, MacMillan, 1988]. Most EE [Neck, Greene, 2011; Ploum et al., 2018] and entrepreneurial competency [Fiet, 2001; Man et al., 2002; Rasmussen et al., 2011; Burnette, 2016] studies have been conducted in countries with strong and long-standing enterprise cultures (i.e., North American and European Community countries) and supportive entrepreneurial ecosystems. The external validity of the findings from the latter studies conducted in generally resource munificent entrepreneurial ecosystems need to be explored [Capaldo et al., 2004] in resource-sparse and hostile entrepreneurial ecosystems. Studies are warranted relating to transition economies where there can be cultural, institutional, and/or resource barriers to careers in enterprise.

EE can be viewed as a pedagogical process [Fayolle et al., 2006] that "... develops individuals' intentions, behaviors, skills, and capabilities and can be applied to create value in a range of contexts and environments...” [NESTA, 2008, p. 12]. Notably, EE can be viewed as an entrepreneurial ecosystem that enables students to accumulate competencies [Neck, Greene, 2011] that increase their intensity of entrepreneurial intention (IOEI). Debate surrounds who should teach EE, who should receive EE, and what EE should teach [OECD, 2011]. Nevertheless, it is generally assumed that EE should focus upon honing student competencies [Lackeus, Middleton, 2018] that can enable them to discover, create, and exploit opportunities in resource munificent as well as resource sparse entrepreneurial ecosystems where they reside [Volery et al., 2015].

Scholars have called for more studies to monitor the outcomes associated with EE [Neck, Greene, 2011; Martin et al., 2013; Walter et al., 2013]. Previous entrepreneurial intention studies have been guided by the theory of planned behavior [Kolvereid, 1996; Solesvik et al., 2012], the entrepreneurial event model [Fitzsimmons and Douglas, 2011], or a combination of these two theories [Iakovleva, Kolvereid, 2009]. Despite the growing plethora of EE courses and studies focusing on EE [Solesvik, 2013; Westhead, Solesvik, 2016], there is still a lack of clarity relating to the links between an individual's specific competencies [Mitchelmore, Rowley, 2010] enhanced by EE and high IOEI. As intimated above, EE that hones an individual's competencies and can be assumed to be a mechanism to enable students to discover, create, and exploit business opportunities, as well as the ability to more quickly address barriers to business formation in resource-sparse and hostile ecosystems where they reside.

Guided by insights from competency theory [Man, Lau, 2000; Man et al., 2002], this exploratory study provides fresh insight relating to this research gap. This study explores two research questions: (1) Are students drawn from a supportive EE and entrepreneurial ecosystem more likely to report high IOEI than students not drawn from a supportive entrepreneurial ecosystem in Ukraine? (2) What specific competencies honed within a supportive EE and entrepreneurial ecosystem is associated with students reporting high IOEI in Ukraine?

This exploratory study replicates and extends studies conducted in North American and European Community contexts. The research questions were explored in a distinct entrepreneurial ecosystem context in the Ukraine. Data was gathered from students drawn from three universities in the city of Nikolaev, which has a population of 500,000 people. This city was the center for shipbuilding in the Soviet Union, but after its collapse the role of shipbuilding dramatically declined. Communist governments widely sought to provide people with employment positions and stable conditions where prices for goods and services exhibited limited variability. Entrepreneurial activity was legally prohib- 
ited, and individual risk-taking was not encouraged. To promote economic development, the Ukrainian government is now supporting $\mathrm{EE}$ to increase the quantity and quality of entrepreneurs, particularly those engaged in knowledge and technology-based activities [Parsyak et al., 2014; Iarmosh, Lototskaya, 2019].

This article is structured as follows. The theoretical case for EE and entrepreneurial ecosystems to focus on honing participants' human capital competency assets is presented in the next section. Hypotheses are then derived. In the following section, the data are collected and the research methodology is discussed. The results are then presented. In the final section, conclusions and implications are presented.

\section{Theoretical Insights}

\section{Competency Theory}

Several definitions of competency have been presented [Hoffmann, 1999]. With reference to the entrepreneur, Iandoli et al. [Iandoli et al., 2007, p. 17] suggested that entrepreneurial competency relates to "the capability of entrepreneurs to face effectively a critical situation by making sense of environmental constraints and by activating relational and internal specific resources." Moreover, Morris et al. [Morris et al., 2013, p. 353] asserted that competency is "the knowledge, skills, attitudes, values, and behaviors that people need to successfully perform a particular activity or task."

Studies have made a distinction between industrial, management, strategic planning, and organizational resource competencies [Lerner, Almor, 2002]. Scholars generally assume that the accumulation of one or more competency will facilitate opportunity discovery, creation and exploitation [Man et al., 2002; Inyang, Enuoh, 2009; Kyndt, Baert, 2015] as well as allow business development barriers to be addressed [Bogatyreva, Shirokova, 2017; Morris et al., 2013]. Studies also recognize the importance of dynamic competencies. Several EE courses now focus on honing entrepreneurial and managerial competencies. Notably, the teaching of competencies needs to be contextualized for the entrepreneurial ecosystems where students reside. The external environment can provide a pool of resources required for business formation and development. Students need to appreciate those cultural norms and values as well as formal and informal rules and regulations that can facilitate and/or retard entrepreneurial behavior [Morris et al., 2013].

Consequently, students drawn from the EE entrepreneurial ecosystem need to accumulate and mobilize competencies that enable them to interact with external actors (i.e., financial institutions, consultants, government advisers, etc.) that can provide the re- sources (i.e., human capital, financial, technological and legitimacy, etc.) required for opportunity discovery, creation, and exploitation. In hostile and resource-constrained entrepreneurial ecosystems, such as the former Soviet Union, students need to accumulate competencies that enable them to gain access to and efficiently use the "limited resources at hand" [Baker, Nelson, 2005].

\section{Entrepreneurial Education}

A distinction has been made between five broad levels of learning [Johannisson, 1991]. The EE entrepreneurial ecosystem can focus on: 'why entrepreneurs act' (i.e., motivation), 'what needs to be done' (i.e., knowledge competency), 'how to do it' (i.e., entrepreneurial and management competencies), 'who should we know' (i.e., network competencies), and 'when to act' (i.e., experience competencies). A key focus of EE is to improve the dynamic human capital assets [Gimeno et al., 1997] of students [Matlay, 2008], particularly their competencies [Miller et al., 2012; Morris et al., 2013; Sanchez, 2013] required to engage in the entrepreneurial process.

\section{Derivation of Hypotheses}

Drawing upon competency theory and insights from EE studies, we present hypotheses relating to the links between EE students' competencies and high IOEI.

\section{Participation in EE}

Diversity has been noted in relation to the links between student participation in EE and high IOEI. Some studies have found no statistically significant link between participation in EE and high IOEI reported by students [Oosterbeek et al., 2008, 2010]; whilst other studies have detected that EE students were significantly more likely to report high IOEI [Sanchez, 2013; Bae et al., 2014; Morris et al., 2017]. Drawing upon insights from competency theory, we assume that students drawn from the EE entrepreneurial ecosystem will hone the human capital competencies required to pursue careers in enterprise. This discussion suggests the following hypothesis:

$H_{1}$ : $\quad$ Students participating in EE will be more likely to report high IOEI.

\section{Participation in EE Promoting Specific Types of Competency Accumulation}

The EE entrepreneurial ecosystem encourages students to improve several specific types of competencies required to discover, create, and exploit business opportunities. Drawing upon competency theory, we assume EE will facilitate the enhancing of a diverse array of different specific types of human 
capital competencies required to pursue careers in enterprise. Hence:

$\mathrm{H}_{2}$ : $\quad$ Students participating in EE that hone their (a) achievement motivation, (b) communication, (c) decisiveness, (d) self-confidence, (e) ability to identify high quality opportunities, $(f)$ computer literacy, (g) project management, (h) negotiation, (i) ability to seize high quality opportunities, (j) technical knowledge, $(k)$ ability to achieve results, (l) ability to make resource allocation decisions that achieve maximum results with limited resources, $(m)$ technical knowledge, or (n) networking competency will report high IOEI.

\section{Data Collected and Research Methodology}

\section{Sample, Data Collection, and Respondents}

$\mathrm{EE}$ is compulsory for economics and business administration students in Ukraine. Information was gathered from a random sample of second year economics and business administration Master's students that participated in EE. EE students were drawn from the European University, the National University of Shipbuilding, and the Petro Mohyla Humanitarian University in the city of Nikolaev, Ukraine. Information was also gathered from a random control group sample of engineering Master's students that were not allowed to participate in EE.

A questionnaire was designed in English. It was then translated into Russian, and then back into English. Russian is an official language in the southern part of the Ukraine. To explore the content and deal with validity issues, a pilot study was conducted with five business and five engineering students at the National University of Shipbuilding. No problems with the questionnaire were detected.

At the European University, 280 business students had taken an EE course by April 2012. A random sample of 45 business EE students were given a paper-based questionnaire during a class and 29 responses were obtained (i.e., $64 \%$ response rate). Information was also gathered from a random sample of 17 engineering students. At the National University of Shipbuilding, 536 business students had taken and EE course by February 2012. A random sample of 100 business EE students were given a paper-based questionnaire during a class and 75 responses were obtained (i.e., $75 \%$ response rate). In addition, data was gathered from a random sample of 47 engineering students. At the Petro Mohyla Humanitarian University, 320 business students had taken an EE course by February 2012. A random sample of 30 business EE students were given a paper-based questionnaire during a class and 21 responses were obtained (i.e., $70 \%$ response rate). No engineering students were contacted due to dif- ficulties relating to access. In total, data was gathered from 125 business EE students and a further 64 engineering students.

The profiles of the 125 business EE student respondents (i.e., $71 \%$ response rate) and the 50 business EE student non-respondents were compared. Chisquare tests failed to detect any significant differences between the business EE student respondents and the business EE student non-respondents with regard to university origin, age, and gender at the 0.05 level of significance. Thus, we have no cause to suspect this sample of EE students is not a representative sample of the population of EE students at the three universities.

\section{Measures}

\section{Dependent Variable}

Liñan and Chen's [Liñan, Chen, 2009] entrepreneurial intention measure was operationalized. Each respondent was presented with six statements relating to the intention to become an entrepreneur. The following statements were presented: I am ready to do anything to be an entrepreneur; my professional goal is to become an entrepreneur; I am determined to create a business venture in the future; I have very seriously thought about starting a firm; I have the intention to start a firm one day; and I intend to start a firm within five years of graduation. Respondents reported their agreement with each statement on a seven-point scale ranging from 'absolutely disagree' (1), 'neither agree nor disagree' (4) and 'absolutely agree' (7). A principal component analysis (PCA) detected that all six statements loaded on a single component. This component had a Cronbach's alpha of 0.92 . Varimax rotated component scores were computed relating to the intention (IOEI) dependent variable.

\section{Independent Variables}

Respondents that participated in EE were allocated a score of ' 1 ', whilst other respondents were allocated a value of ' 0 ' (EE). Moreover, each respondent was presented with thirteen statements relating to their perceived competencies. The 13 competencies monitored related to: achievement motivation (Achievement), communication (Communication), decisiveness (Decisiveness), selfconfidence (Confidence), ability to identify high quality opportunities (Identify), computer literacy (Computer), project management (Project), negotiation (Negotiation), ability to seize high quality opportunities (Seize), technical knowledge (Technical), ability to achieve results (Results), ability to make resource allocation decisions that achieve maximum results with limited resources (Resources), and networking (Networking). Respondents reported their 
Table 1. Descriptive Statistics and Correlation Matrix $(\mathbf{n}=\mathbf{1 8 9})^{(\mathrm{a})(\mathrm{b})}$

\begin{tabular}{|c|c|c|c|c|c|c|c|c|c|c|c|c|c|c|c|c|c|c|c|c|c|}
\hline Variables & Mean & SD & VIF & 1 & 2 & 3 & 4 & 5 & 6 & 7 & 8 & 9 & 10 & 11 & 12 & 13 & 14 & 15 & 16 & 17 & 18 \\
\hline 1. Female & 1.56 & 0.50 & 1.01 & 1.00 & & & & & & & & & & & & & & & & & \\
\hline 2. Age & 20.35 & 1.59 & 1.02 & -0.12 & 1.00 & & & & & & & & & & & & & & & & \\
\hline 3. Parents & 0.42 & 0.49 & 1.01 & 0.04 & \begin{tabular}{|l|}
-0.06 \\
\end{tabular} & 1.00 & & & & & & & & & & & & & & & \\
\hline 4. $\mathrm{EE}$ & 0.66 & 0.47 & 1.47 & $0.58^{* *}$ & 0.02 & $0.16^{*}$ & 1.00 & & & & & & & & & & & & & & \\
\hline 5. Achievement & 3.62 & 1.11 & 2.06 & $0.15^{*}$ & 0.02 & -0.04 & $0.26^{\prime \prime}$ & 1.00 & & & & & & & & & & & & & \\
\hline 6. Communication & 3.86 & 1.13 & 2.35 & $0.20^{*}$ & \begin{tabular}{|l|}
-0.12 \\
\end{tabular} & -0.05 & $0.31^{* \prime}$ & $0.56^{\prime \prime}$ & 1.00 & & & & & & & & & & & & \\
\hline 7. Decisiveness & 3.82 & 1.14 & 2.90 & $0.19^{*}$ & 0.06 & 0.01 & $0.25^{* \prime}$ & $0.57^{\prime \prime}$ & $0.62^{* *}$ & 1.00 & & & & & & & & & & & \\
\hline 8. Confidence & 3.72 & 1.08 & 2.53 & $0.16^{*}$ & 0.10 & 0.01 & $0.23^{* *}$ & $0.53^{* *}$ & $0.48^{* *}$ & $0.68^{* * 1} 1$ & 1.00 & & & & & & & & & & \\
\hline 9. Identify & 3.57 & 1.04 & 2.74 & 0.08 & \begin{tabular}{|l|l}
0.03 \\
\end{tabular} & $0.15^{*}$ & 0.13 & $0.53^{* 1 *}$ & $0.44^{*}$ & $0.65^{* *} \mathrm{C}$ & 0.63 & 1.00 & & & & & & & & & \\
\hline 10. Computer & 3.85 & 1.19 & 1.57 & $0.19^{*}$ & \begin{tabular}{|l|}
-0.01 \\
\end{tabular} & 0.14 & $0.18^{*}$ & $0.42^{* *}$ & $0.51^{* *}$ & $0.57^{* * 1} \mathrm{C}$ & $0.45^{x+1}$ & $0.52^{* *}$ & 1.00 & & & & & & & & \\
\hline 11. Project & 3.59 & 1.09 & 2.58 & 0.14 & -0.03 & $0.20^{* *}$ & $0.16^{*}$ & $0.49^{* *}$ & $0.43^{* *}$ & $0.52^{* *} \mathrm{C}$ & $0.45^{x+1}$ & $0.62^{* *}$ & $0.66^{* 1+}$ & 1.00 & & & & & & & \\
\hline 12. Negotiation & 3.64 & 1.26 & 2.02 & 0.14 & 0.01 & 0.14 & $0.28^{* *}$ & $0.45^{* *}$ & $0.40^{* *}$ & $0.52^{* *} \mathrm{C}$ & $0.47^{* *}$ & $0.55^{* *}$ & $0.54^{* *+}$ & $0.57^{* x}$ & 1.00 & & & & & & \\
\hline 13. Seize & 3.60 & 1.14 & 2.93 & 0.14 & -0.03 & 0.11 & $0.21^{* *}$ & $0.46^{* *}$ & $0.48^{* *}$ & $0.54^{* *} \mathrm{C}$ & $0.52^{* *}$ & $0.58^{* *+}$ & $0.59^{* *+}$ & $0.61^{* *}$ & $0.58^{x+1}$ & 1.00 & & & & & \\
\hline 14. Technical & 3.72 & 1.07 & 2.23 & -0.02 & -0.02 & 0.15 & $0.19^{* *}$ & $0.45^{* \prime}$ & $0.43^{*+}$ & $0.49^{+* *} \mathrm{C}$ & $0.41^{* *}$ & $0.56^{*+}$ & $0.50^{* *}$ & $0.54^{*}$ & $0.57^{* *}$ & $0.51^{* *}$ & 1.00 & & & & \\
\hline 15. Results & 3.66 & 1.14 & 2.77 & 0.13 & 0.04 & 0.09 & $0.20^{* *}$ & $0.46^{* 1}$ & $0.52^{* *}$ & $0.53^{* *} \mathrm{C}$ & $0.46^{*}$ & $0.59^{*+1}$ & $0.51^{* *}$ & $0.55^{* *}$ & $0.53^{x+1}$ & $0.69^{* *}$ & $0.59^{* *}$ & 1.00 & & & \\
\hline 16. Resources & 3.65 & 1.07 & 2.55 & 0.11 & -0.01 & 0.12 & $0.22^{* *}$ & $0.51^{* *} \mathrm{C}$ & $0.47^{* *}$ & $0.53^{* *} \mathrm{C}$ & $0.42^{* *}$ & $0.60^{*+1}$ & $0.56^{*}$ & $0.62^{* *}$ & $0.57^{* *}$ & $0.63^{* *} \mathrm{C}$ & $0.58^{* 1}$ & $0.66^{* *}$ & 1.00 & & \\
\hline 17. Networking & 3.83 & 1.13 & 2.78 & $0.15^{*}$ & -0.01 & 0.12 & $0.25^{* \prime}$ & $0.44^{* *}$ & $0.41^{* *}$ & $0.58^{* * 1} \mathrm{C}$ & $0.51^{x *}$ & $0.56^{*}$ & $0.54^{*}$ & $0.50^{-1 .}$ & $0.53^{x+1}$ & $0.69^{* * 1}$ & $0.53^{* 1}$ & $0.61^{* *}$ & $0.63^{*+}$ & 1.00 & \\
\hline 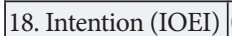 & 0.044 & 0.98 & & 0.04 & $0.16^{*}$ & 0.16 & 0.21 " & [0.31"] & 23 & 10.30 & & |0.38 & 10.24 & $\mid 0.34$ & ] & 10.37 & {$[0.23$} & 10.38 & ]0.28 & & \\
\hline
\end{tabular}

Notes: (a) Means and standard deviations (SD), (b) IOEI relates to a summative scale, (c) ${ }^{\star} \mathrm{p}<005$ (two-tailed), ${ }^{* \star} \mathrm{p}<0.01$ (two-tailed).

Source: authors

agreement with each statement on a five-point scale ranging from 'absolutely disagree' (1), 'neither agree nor disagree' (3) and 'absolutely agree' (5).

\section{Control Variables}

Human capital variables considered in previous studies were selected as control variables. Female respondents were allocated a value of ' 1 ', whilst male respondents were allocated a value of ' 0 ' (Female). Investments in human capital may decrease exponentially with age [Cressy, 1996]. The age of the respondents was measured in years (Age). Respondents from family firm backgrounds were allocated a value of ' 1 ', whilst others were allocated a value of '0' (Family).

\section{Data Analysis}

Table 1 provides means, standard deviations, and correlations. The variance inflation factor (VIF) scores suggest that multicollinearity is not a problem. To test the hypotheses, hierarchical ordinary least squares (OLS) regression models are reported. A base model relating to the control variables is presented. Participation in EE was then added to the base control variable model. The next model included all 13 specific types of competencies honed by EE. The significance of the adjusted $\mathrm{R}^{2}$ coefficients relating to each model was checked. Further, the change in $\mathrm{R}^{2}$ relating to the sequential inclusion of the alternative $\mathrm{EE}$ measures was monitored.

\section{Results}

Model 1 included the control variables and is not significant at the 0.1 level (Table 2). Model 2 focusing on participation in EE had an adjusted $\mathrm{R}^{2}$ of 0.08 and is significant at the 0.01 level. One of the three control variables was significant. Respondents drawn from family firm backgrounds reported weakly significantly higher IOEI at the 0.1 level. Notably, EE respondents reported significantly higher IOEI at the 0.05 level. Consequently, hypothesis 1 was confirmed.

Independent variables relating to the competencies were included in Model 3. This model has an adjusted $R^{2}$ of 0.31 and is significant at the 0.001 level. None of the control variables were significant. EE respondents reported significantly higher IOEI at the 0.05 level. Three out of the 13 competencies were weakly significant the 0.1 level. Respondents that reported the ability to identify high quality opportunities (Quality), computer literacy (Computer), or networking (Networking) reported higher IOEI. Consequently, hypotheses $\mathrm{H} 2 \mathrm{e}, \mathrm{H} 2 \mathrm{f}$ and $\mathrm{H} 2 \mathrm{n}$ were weakly supported.

\section{Conclusions and Implications}

This exploratory study adds to the understanding of the growing EE entrepreneurial ecosystem phenomenon by providing novel insights from a representative sample of students reporting higher intensity of entrepreneurial intention (IOEI). Supporting the 
Table 2. Entrepreneurial Education and Competencies Associated with Intensity of Intention (IOEI): Ordinary Least Squares (OLS) Hierarchical Regression Models Estimating the Direct Effects (OLS) $(\mathbf{n}=189)$

\begin{tabular}{|c|c|c|c|}
\hline & Model 1 & Model 2 & Model 3 \\
\hline \multicolumn{4}{|c|}{ Control variables } \\
\hline Female & 0.02 & -0.13 & -0.17 \\
\hline Age & 0.04 & 0.02 & 0.02 \\
\hline Parents & $0.20^{\star *}$ & $0.16^{*}$ & 0.09 \\
\hline \multicolumn{4}{|c|}{ Independent variables } \\
\hline $\mathrm{EE}$ & & $0.27^{\star *}$ & $0.25^{\star *}$ \\
\hline Achievement & & & $0.22^{\star}$ \\
\hline Communication & & & -0.09 \\
\hline Decisiveness & & & -0.10 \\
\hline Confidence & & & -0.13 \\
\hline Identify & & & $0.24^{*}$ \\
\hline Computer & & & -0.13 \\
\hline Project & & & $0.21^{*}$ \\
\hline Negotiation & & & -0.11 \\
\hline Seize & & & 0.19 \\
\hline Technical & & & -0.14 \\
\hline Results & & & 0.10 \\
\hline Resources & & & -0.18 \\
\hline Networking & & & $0.24^{*}$ \\
\hline $\mathrm{R}^{2}$ & 0.04 & 0.08 & 0.31 \\
\hline Adjusted $\mathrm{R}^{2}$ & 0.02 & 0.06 & 0.23 \\
\hline F value & 2.32 & 3.19 & 4.03 \\
\hline Sig. F value & 0.091 & 0.006 & 0.000 \\
\hline Adjusted $\mathrm{R}^{2}$ change & 0.02 & 0.04 & 0.17 \\
\hline F change & & 7.99 & 3.69 \\
\hline Sig. F change & & 0.005 & 0.000 \\
\hline \multicolumn{4}{|c|}{$\begin{array}{l}\text { Note: }{ }^{*} \mathrm{p}<0.10 ;{ }^{* *} \mathrm{p}<0.05 \\
\text { Source: authors.. }\end{array}$} \\
\hline
\end{tabular}

external validity of findings from EE studies conducted in developed economies, this study focusing upon the transitional context of Ukraine confirmed that students drawn from a supportive EE entrepreneurial ecosystem were associated with higher IOEI. This study also provides novel insights relating to the focus of EE. Developed economy studies generally suggest that the honing of competencies will promote higher student IOEE. With regard to 13 competencies, this study interestingly detected that only three competencies (i.e., ability to identify high quality opportunities, computer literacy, and networking) were weakly significantly associated with higher student IOEI. Additional research is warranted surrounding this disappointing finding from an $\mathrm{EE}$ entrepreneurial ecosystem perspective. In part, this finding could be due to the EE method of improving of competencies. EE teachers may need to appreciate the fact that the competencies honed in developed economies may not be the competencies required to promote higher student IOEI in resource sparse and hostile entrepreneurial ecosystems as are in former USSR republics. In the latter entrepreneurial ecosystems, there still may be significant ingrained cultural barriers to enterprise despite the recent efforts of governments to highlight the benefits associated with a free market economy. Further, in some entrepreneurial ecosystems there can be powerful existing entrepreneurs that do not want to face competition from additional entrepreneurs with novel ideas ('predatory entrepreneurs' according to [Feige, 1997]). For example, there may be a need for the content and deliveries of EE to be contextualized in the entrepreneurial ecosystems where students reside relating to local resource availability and barriers to enterprise. Former Soviet entrepreneurial ecosystems are not a homogeneous entity. The external validity of the findings from this sample of EE and non-EE students needs to be explored in more studies in Ukraine. Also, they need to be explored in several diverse entrepreneurial ecosystems (i.e., resource munificent as well as resource sparse and hostile) in former Soviet republics.

The student population is diverse in terms of gender and family background. Governments in developed economies are seeking to address social and regional inequality with regard to the pursuit of careers in enterprise. This exploratory study found that students drawn from family firm backgrounds reported weakly significantly higher IOEI. It could be assumed that students not drawn from a family firm background, female students, and those that reside in localities with limited resources for enterprise may markedly benefit more from EE. To better contextualize EE, additional studies are warranted surrounding the backgrounds of students and links with higher IOEI. Results from the recent Global University Entrepreneurial Students' Spirit Survey (GUESSS) relating to EE and non-EE students will provide additional insights surrounding the benefits associated with the EE entrepreneurial ecosystem in Ukraine and in a diverse array of former Soviet and Western contexts.

Governments require a rigorous evidence base to guide their resource allocation decisions to support the EE entrepreneurial ecosystem or not. Evidence from this exploratory study suggests the jury should be still out. Governments need to be presented with conclusive evidence that the EE entrepreneurial ecosystem and the competencies and knowledge honed by EE significantly foster higher IOEI reported by students. This exploratory study relating to a sample of EE students in one region in Ukraine does not provide conclusive evidence for a government to more proactively support the EE entrepreneurial ecosystem with regard to its current content and delivery. 


\section{References}

Bae T.J., Qian S., Miao C., Fiet J.O. (2014) The relationship between entrepreneurship education and entrepreneurial intentions: A meta-analytic review. Entrepreneurship Theory and Practice, vol. 38, no 2, pp. 217-254.

Baker T., Nelson R.E. (2005) Creating something from nothing: Resource construction through entrepreneurial bricolage. Administrative Science Quarterly, vol. 50, no 3, pp. 329-366.

Bogatyreva K., Shirokova G. (2017) From entrepreneurial aspirations to founding a business: The case of Russian students. Foresight and STI Governance, vol. 11, no 3, pp. 25-36.

Burnette D.M. (2016) The renewal of competency-based education: A review of the literature. The Journal of Continuing Higher Education, vol. 64, no 2, pp. 84-93.

Capaldo G., Iandoli L., Ponsiglione C. (2004) Entrepreneurial competencies and training needs of small firms. Paper presented at the 14th Annual IntEnt Conference, 4-7 July, 2004, Napoli, Italy.

Chepurenko A. (2015) Entrepreneurship theory: New challenges and future prospects. Foresight and STI Governance, vol. 9, no 2, pp. 44-57.

Colombo M.G., Grilli L. (2005) Founders' human capital and the growth of new technology-based firms: A competencebased view. Research Policy, vol. 34, no 6, pp. 795-816.

Cressy D. (1996) Gender trouble and cross-dressing in early modern England. Journal of British Studies, vol. 35, no 4, pp. $438-465$.

European Commission (2008) Entrepreneurship in Higher Education, Especially in Non-Business Studies, Brussels: European Commission. Available at: http://ec.europa.eu/ enterprise/policies/sme/files/support_measures/training_education/ entr_highed_en.pdf, accessed 04.03.2019.

Fayolle A., Gailly B., Lassas-Clerc N. (2006) Assessing the impact of entrepreneurship education programmes: A new methodology. Journal of European Industrial Training, vol. 30, no 9, pp. 701-720.

Feige E. (1997) Underground Activity and Institutional Change: Productive, Protective and Predatory Behavior in Transition Economies. Transforming Post-Communist Political Economies (eds. J. Nelson, C. Tilly, L. Walker), Washington, D.C.: National Academy Press, pp. 21-35.

Fiet J.O. (2000) The theoretical side of teaching entrepreneurship. Journal of Business Venturing, vol. 16, no 1, pp. 1-24.

Fitzsimmons J. R., Douglas E. (2011) Interaction between feasibility and desirability in the formation of entrepreneurial intentions. Journal of Business Venturing, vol. 26, no 4, pp. 431-440.

Gibb A., Haskins G., Robertson I. (2009) Leading the Entrepreneurial University: Meeting the Entrepreneurial Development Needs of Higher Education Institutions, Coventry: National Council for Graduate Entrepreneurship.

Gimeno J., Folta T.B., Cooper A.C., Woo C.Y. (1997) Survival of the fittest? Entrepreneurial human capital and the persistence of underperforming firms. Administrative Science Quarterly, vol. 42, no 4, pp. 750-783.

Hoffmann T. (1999) The meanings of competency. Journal of European Industrial Training, vol. 23, no 6, pp. 275-286.

Iakovleva T., Kolvereid L. (2009) An integrated model of entrepreneurial intentions. International Journal of Business and Globalisation, vol. 3, no 1, pp. 66-80.

Iandoli L., Landström H., Raffa M. (2007) Introduction: Entrepreneurship, competitiveness and local development. Entrepreneurship, Competitiveness and Local Development: Frontiers in European Entrepreneurship Research (eds. L. Iandoli, H. Landström, M. Raffa), Cheltenham: Edward Elgar Publishing, pp. 1-24.

Iarmosh O., Lototskaya E. (2019) New opportunities for youth entrepreneurship development and youth self-employment increase. Adaptive Management: Theory and Practice. Economics, vol. 6, no 12, pp. 1-19.

Inyang B.J., Enuoh R.O. (2009) Entrepreneurial competencies: The missing links to successful entrepreneurship in Nigeria. International Business Research, vol. 2, no 2, pp. 62-71.

Johannisson B. (1991) University training for entrepreneurship: Swedish approaches. Entrepreneurship \& Regional Development, vol. 3, no 1, pp. 67-82.

Kolvereid L. (1996) Prediction of employment status choice intentions. Entrepreneurship Theory and Practice, vol. 21, no 1, pp. 47-58.

Kwapisz A. (2019) Do government and legal barriers impede entrepreneurship in the US? An exploratory study of perceived vs. actual barriers. Journal of Business Venturing Insights, vol. 11, article e00114. Available at: https://doi.org/10.1016/j. jbvi.2019.e00114, accessed 15.09.2019.

Kyndt E., Baert H. (2015) Entrepreneurial competencies: Assessment and predictive value for entrepreneurship. Journal of Vocational Behavior, vol. 90, no 1, pp. 13-25. 
Lackéus M., Middleton K.W. (2018) Assessing experiential entrepreneurship education: Key insights from five methods in use at a venture creation programme. Experiential Learning for Entrepreneurship (eds. D. Hyams-Ssekasi, E. Caldwell), Basingstoke (UK): Palgrave Macmillan, pp. 19-49.

Lerner M., Almor T. (2002) Relationships among strategic capabilities and the performance of women-owned small ventures. Journal of Small Business Management, vol. 40, no 2, pp. 109-125.

Liñán F., Chen Y.W. (2009) Development and cross-cultural application of a specific instrument to measure entrepreneurial intentions. Entrepreneurship Theory and Practice, vol. 33, no 3, pp. 593-617.

Low M.B., MacMillan I.C. (1988) Entrepreneurship: Past research and future challenges. Journal of Management, vol. 14, no 2, pp. 139-161.

Malecki E.J. (2018) Entrepreneurship and entrepreneurial ecosystems. Geography Compass, vol. 12, no 3, article e12359. Available at: https://doi.org/10.1111/gec3.12359, accessed 15.09.2019.

Man T., Lau T. (2000) Entrepreneurial competencies of SME owner/managers in the Hong Kong service sector: A qualitative analysis. Journal of Enterprising Culture, vol. 8, no 3, pp. 235-254.

Man T., Lau T. (2005) The context of entrepreneurship in Hong Kong: An investigation through the patterns of entrepreneurial competencies in contrasting industrial environments. Journal of Small Business and Enterprise Development, vol. 12, no 4 , pp. 464-481.

Man T., Lau T., Chan K.F. (2002) The competitiveness of small and medium enterprises: A conceptualization with focus on entrepreneurial competencies. Journal of Business Venturing, vol. 17, no 2, pp. 123-142.

Martin B.C., McNally J.J., Kay M.J. (2013) Examining the formation of human capital in entrepreneurship: A meta-analysis of entrepreneurship education outcomes. Journal of Business Venturing, vol. 28, no 2, pp. 211-224.

Matlay H. (2008) Vocational education, training and learning in smaller businesses. Education + Training, vol. 50, no 8/9, pp. $1-2$.

Miller T.L., Wesley C.L., Williams D.E. (2012) Educating the minds of caring hearts: Comparing the views of practitioners and educators on the importance of social entrepreneurship competencies. Academy of Management Learning \& Education, vol. 11, no 3, pp. 349-370.

Mitchelmore S., Rowley J. (2010) Entrepreneurial competencies: A literature review and development agenda. International Journal of Entrepreneurial Behavior and Research, vol. 16, no 2, pp. 92-111.

Morris M.H., Shirokova G., Tsukanova T. (2017) Student entrepreneurship and the university ecosystem: A multi-country empirical exploration. European Journal of International Management, vol. 11, no 1, pp. 65-85.

Morris M.H., Webb J.W., Fu J., Singhal S. (2013) A competency based perspective on entrepreneurship education: conceptual and empirical insights. Journal of Small Business Management, vol. 51, no 3, pp. 352-369.

Neck H.M., Greene P.G. (2011) Entrepreneurship education: Known worlds and new frontiers. Journal of Small Business Management, vol. 49, no 1, pp. 55-70.

NESTA (2008) Developing Entrepreneurial Graduates: Putting Entrepreneurship at the Center of Higher Education, London: NESTA.

OECD (2011) Partnering for Success in Fostering Graduate Entrepreneurship. OECD LEED Forum on Partnerships and Local Governance. Handbook No. 5, Paris: OECD.

Oosterbeek H., van Praag M., Ijsselstein A. (2008) The impact of entrepreneurship education on entrepreneurship competencies and intentions (Tinbergen Institute Discussion Paper 08-038/3), Amsterdam: Tinbergen Institute.

Oosterbeek H., Van Praag M., Ijsselstein A. (2010) The impact of entrepreneurship education on entrepreneurship skills and motivation. European Economic Review, vol. 54, no 3, pp. 442-454.

Parsyak V.N., Solesvik M., Parsyak K.V. (2014) Economic aspects of formation and development of entrepreneurship education. Actual Problems of Economics, vol. 15, no 5, pp. 126-133.

Ploum L., Blok V., Lans T., Omta O. (2018) Toward a validated competence framework for sustainable entrepreneurship. Organization \& Environment, vol. 31, no 2, pp. 113-132.

Rasmussen E., Mosey S., Wright M. (2011) The evolution of entrepreneurial competencies: A longitudinal study of university spin-off venture emergence. Journal of Management Studies, vol. 48, no 6, pp. 1314-1345.

Sánchez J.C. (2013) The impact of an entrepreneurship education program on entrepreneurial competencies and intention. Journal of Small Business Management, vol. 51, no 3, pp. 447-465.

Schwens C., Zapkau F.B., Bierwerth M., Isidor R., Knight G., Kabst R. (2018) International entrepreneurship: A metaanalysis on the internationalization and performance relationship. Entrepreneurship Theory and Practice, vol. 42, no 5, pp. 734-768. 
Solesvik M. (2013) Entrepreneurial motivations and intentions: Investigating the role of education major. Education + Training, vol. 55, no 3, pp. 253-271.

Solesvik M., Westhead P., Kolvereid L., Matlay H. (2012) Student intentions to become self-employed: The Ukrainian context. Journal of Small Business and Enterprise Development, vol. 19, no 3, pp. 441-460.

Volery T., Mueller S., von Siemens B. (2015) Entrepreneur ambidexterity: A study of entrepreneur behaviors and competencies in growth-oriented small and medium-sized enterprises. International Small Business Journal, vol. 33, no 2, pp. 109-129.

Walter S.G., Parboteeah K.P., Walter A. (2013) University departments and self-employment intentions of business students: A cross-level analysis. Entrepreneurship Theory and Practice, vol. 37, no 2, pp. 175-200.

Weerawardena J., Salunke S., Knight G., Mort G.S., Liesch P.W. (2019) The learning subsystem interplay in service innovation in born global service firm internationalization. Industrial Marketing Management (forthcoming). Available at: https:// doi.org/10.1016/j.indmarman.2019.05.012, accessed 15.09.2019.

Westhead P., McElwee G., Wright M. (2011) Entrepreneurship: Perspectives and Cases, London: Pearson Education.

Westhead P., Solesvik M. (2016) Entrepreneurship education and entrepreneurial intention: Do female students benefit? International Small Business Journal, vol. 34, no 8, pp. 979-1003.

Zahra S.A., Nambisan S. (2012) Entrepreneurship and strategic thinking in business ecosystems. Business Horizons, vol. 55, no 3, pp. 219-229. 